\title{
ARTICLES
}

\section{Approach with Caution}

\section{Sunset Clauses as Safeguards of Democracy?}

Sean Molloy*

\section{Abstract}

In response to the COVID-19 pandemic, leaders across the globe scrambled to adopt emergency legislation. Amongst other things, these measures gave significant powers to governments in order to curb the spreading of a virus, which has shown itself to be both indiscriminate and deadly. Nevertheless, exceptional measures, however necessary in the short term, can have adverse consequences both on the enjoyment of human rights specifically and democracy more generally. Not only are liberties severely restricted and normal processes of democratic deliberation and accountability constrained but the duration of exceptional powers is also often unclear. One potentially ameliorating measure is the use of sunset clauses: dispositions that determine the expiry of a law or regulation within a predetermined period unless a review determines that there are reasons for extension. The article argues that without effective review processes, far from safeguarding rights and limiting state power, sunset clauses can be utilized to facilitate the transferring of emergency powers whilst failing to guarantee the very problems of normalized emergency they are included to prevent. Thus, sunset clauses and the review processes that attach to them should be approached with caution.

Keywords: emergency legislation, sunset clauses, post-legislative review, COVID-19.

\section{A Introduction}

In response to the COVID-19 pandemic, governments across the globe scrambled to adopt emergency legislation in order to limit the impacts of the virus on their population. There were, however, differences in approach. Some, such as South Africa, Portugal, Armenia, Estonia, Georgia, Latvia, Moldova and Romania, have de- 
clared a state of emergency or disaster. ${ }^{1}$ A state of emergency is the special legal regime of powers and rules that is brought into operation when a country faces a grave threat. ${ }^{2}$ The delegation of extraordinary powers to issue decrees and suspend legal processes and rights are theoretically justified as resolving the threat to the system and restoring it to its previous constitutional state. ${ }^{3}$ At least in theory, declaring a state of emergency provides a legal framework under which derogations from normal processes and laws are permitted. ${ }^{4}$ For example, under Article 15 of the European Convention on Human rights, states are permitted to derogate in time of war or other public emergency threatening the life of the nation', but only 'to the extent strictly required by the exigencies of the situation.' ${ }^{5}$ International laws can also proscribe limits on what is and is not permitted under a state of emergency. ${ }^{6}$ Many national constitutions also stipulate when and why a state of emergency might be declared, who is permitted to do so, the role of the legislature in scrutinizing emergency powers, the geographical scope of the emergency measures, their duration and methods for termination, the role of the courts in supervising them and limitations on what can be done. ${ }^{7}$ For instance, the Constitution of Estonia, pursuant to Article 130, stipulates that certain rights are always protected, even during an emergency, including citizenship rights, procedural rights and guarantees of the rule of law, the right to life and the prohibition of torture, as examples.

Scholars such as Alan Greene thus assess that if the exigencies of the COVID-19 pandemic require exceptional measures and deviation from some dimensions of the full enjoyment of all human rights, then it is best to introduce those measures through a framework that entails a commitment to legality and to the full restoration of normalcy as soon as possible. ${ }^{8}$ The strength of this argument is, of course, dependent on the strength of constitutionalism in a country or level of compliance

1 See Alan Greene, 'State of Emergency: How Different Countries are Invoking Extra Powers to Stop the Coronavirus', The Conversation (30 March 2020); Melodie Labuschaigne \& Ciara Staunton, 'COVID-19: State of Disaster in South Africa', Verfassungsblog (11 April 2020); Teresa Violante \& Rui T. Lanceiro, 'Coping with Covid-19 in Portugal: From Constitutional Normality to the State of Emergency’, Verfassungsblog (12 April 2020).

2 See Fionnuala Ní Aoláin \& Oren Gross, Law in Times of Crisis: Emergency Powers in Theory and Practice (Cambridge: Cambridge University Press, 2006); Alan Greene, Permanent States of Emergency and the Rule of Law Constitutions in an Age of Crisis (Oxford: Hart Publishing, 2018).

3 Jaclyn Neo \& Darius Lee, 'Singapore's Legislative Approach to the COVID-19 Public Health "Emergency", Verfassungsblog (18 April 2020).

4 See Elliot Bulmer (2016), Emergency Powers, International IDEA Constitution-Building Primer, at 18.

5 European Convention on Human Rights, Art. 15.

6 For instance, the International Covenant on Civil and Political Rights (ICCPR) similarly provides that certain rights are 'non-derogatable' (i.e. cannot be suspended or restricted) even in emergencies. These include the right to life (Art. 6), freedom from torture (Art. 7), prohibition of slavery (Art. 8), no imprisonment for debt (Art. 11), no punishment without law or retrospective penalties (Art. 15), recognition as a person in law (Art. 16) and freedom of religion (Art. 18).

7 See Sean Molloy, Negotiating States of Emergency, Political Settlements Research Programme Report, 2020; Elliot W. Bulmer (2016), Emergency Powers, International IDEA Constitution-Building Primer, at 18.

8 Alan Greene, 'States Should Declare a State of Emergency Using Article 15 ECHR to Confront the Coronavirus Pandemic', Strasbourg Observers, Art. 15, Covid-19 (1 April 2020). 
with international human rights standards more generally. ${ }^{9}$ In general, and whilst often framed under various headings, ${ }^{10}$ there is ample evidence of the gradual erosion of constitutional checks and balances globally and there is no shortage of examples of national governments utilizing a state of emergency in the context of COVID-19 to further entrench power, institutional checks and balances notwithstanding. ${ }^{11}$ Nevertheless, as a point of departure, declaring a state of emergency is one method by which to ensure that emergency measures exist within a legal framework.

Alternatively, whilst many states have enacted what have been described as emergency laws in response to the coronavirus pandemic, not all have declared a state of emergency under law. In some cases, new legislation is adopted. For instance, in the United Kingdom, the Coronavirus Act (2020) was passed to manage the coronavirus outbreak. ${ }^{12}$ The Act introduced a wave of measures designed to either amend existing legislative provisions or introduce new statutory powers in order to mitigate the effects of the COVID-19 pandemic. In Scotland, the Coronavirus (Scotland) Act 2020 was promulgated, whilst in Ireland, The Health (Preservation and Protection and other Emergency Measures in the Public Interest) Act 2020 was passed by both houses of the Oireachtas (the Irish Parliament) and was signed into law by the President on 20 March 2020. In other cases, countries have relied on existing legislation, often in the form of Health Acts to provide the legal basis for sweeping powers for detention, quarantine and even lockdown, frequently amending these laws as the pandemic unfolds. Differing still and confusingly, some appear to adopt a dual approach. For example, notwithstanding the adoption of the Coronavirus Act, in the United Kingdom the powers as they pertain to lockdown have consistently come in the form of enabling legislation under the Public Health (Control of Disease) Act 1984.

These variations notwithstanding, as with a state of emergency, the central purpose of emergency legislation is to enable governments to respond to the exigencies of the situation through concentration of increased power in the hands of the executive. This often means that public officials are allowed to limit fundamen-

9 Joelle Grogan, 'States of Emergency', Verfassungsblog (26 May 2020).

10 Nancy Berneo (2016), 'On Democratic Backsliding', Journal of Democracy, 27(1); Tom Gerald Daly, 'Democratic Decay: The Threat with a Thousand Names' (LSE US Centre Blog); Tom Daly (2019), 'Democratic Decay: Conceptualising an Emerging Research Field', Hague Journal on the Rule of Law, 11(9); Kim Lane Scheppele \& Laurent Pech, 'What Is Rule of Law Backsliding?', Verfassungsblog (2 March 2018); Aziz Huq \& Tom Ginsburg, How to Save a Constitutional Democracy (Chicago: University of Chicago Press, 2018).

11 See, e.g. Randle Defalco, 'Opportunism, COVID-19, and Cambodia's State of Emergency Law,' Just Security (3 August 2020); Radosveta Vassileva, 'Bulgaria: COVID-19 as an Excuse to Solidify Autocracy?', Verfassungsblog (10 April 2020); Gábor Halmai \& Kim Lane Scheppele, 'Don't Be Fooled by Autocrats!', Verfassungsblog (22 April 2020); Elizabeth Donkervoort, 'While Autocrats Exploit the Pandemic, Citizens Fight It', Democracy Speaks Blog (16 April 2020); Jakub Jaraczewski, 'An Emergency By Any Other Name? Measures Against the COVID-19 Pandemic in Poland', Verfassungsblog (24 April 2020); Kriszta Kovács, 'Hungary's Orbánistan: A Complete Arsenal of Emergency Powers', Verfassungsblog (6 April 2020).

12 Clive Walker \& Andrew Blick, 'Coronavirus Legislative Responses in the UK: Regression to Panic and Disdain of Constitutionalism', Just Security (12 May 2020). 
tal guarantees, enacting measures to protect a nation confronted with grave peril. ${ }^{13}$ Differing from a state of emergency, however, the same overarching legal framework that both permits and limits the transfer of extraordinary power is often missing. We might say then that whilst emergency legislation adopted outside of a state of emergency attempts to achieve the same balance of enabling the government to respond, whilst at the same time remaining within the law and limiting the exceptional, there does not exist the same guarantees provided under constitutional or international human rights law.

Against this backdrop, this article examines the use of sunset clauses as a potentially ameliorating measure; one that seeks to facilitate the necessary flexibility required to respond to emergencies through legislation, whilst at the same time preventing the normalization of exceptional measures, and reinjecting democratic deliberation and accountability through review processes. Sunset clauses are a legislative technique employed when passing emergency legislation with two primary elements: (i) limited duration and (ii) ex post evaluation. As the word suggests, a sunset clause does not aim at continuity; rather, it 'sets the sun' on a provision or entire statute on a specific date, unless there are substantial reasons to believe that the former should be extended for a determined period. ${ }^{14}$ This termination or renewal should only occur after an ex post evaluation has taken place. This evaluation looks at the [effects of the sunset disposition and verifies whether the objective for which it was enacted has been achieved, or whether the provision should be renewed for a determined period. ${ }^{15}$ As scholars such as McGarrity et al. note, it is often unclear what it means for a sunset clause to be 'effective'. ${ }^{16}$ In many ways, the question is context dependent, subject to both the wider setting in which emergency powers are adopted and the ongoing nature of the emergency. In order to situate the use of sunset clauses in the context of emergency legislation, Section B traces a number of difficulties associated with emergency legislation. This includes the way it is adopted, the powers afforded under emergency law and risks of normalization, as well as accountability deficits. Section $C$ then considers how, in theory, sunset clauses can respond to and address these concerns, whilst Section D questions a number of these assumptions. The article concludes by arguing in favour of a healthy degree of scepticism when it comes to the virtue of sunset clauses and utilizing this caution to help inform review processes of emergency legislation as and when they arise.

\section{B The Problems of Emergency Legislation}

The term 'emergency' connotes a sudden, urgent, usually unforeseen event or situation that requires immediate action, often without time for prior reflection and Emergencies', Minnesota Journal of International Law, 25(1), at 52.

14 Sofia Ranchordás (2015), 'Sunset Clauses and Experimental Regulations: Blessing or Curse for Legal Certainty?', Statute Law Review, 36(1), at 30.

15 Ibid.

16 Nicola McGarrity, Rishi Gulati \& George Williams (2012), 'Sunset Clauses in Australian Anti-Terror Laws', Adelaide Law Review, 33(2), at 308. 
consideration. ${ }^{17}$ The idea of emergency legislation is a direct response to the emergency in question. It provides the impetus and justification both for the powers that are transferred to deal with the situation at hand and the expedited nature in which the relevant laws are enacted. Nevertheless, there are many dangers associated with doing so. In order to understand the potential importance of sunset clauses and the review processes that attaches to them, the discussion below considers three externalities associated with emergency legislation, namely democratic deficits in the legislative process, the risk of extraordinary measures of normalizing and limited accountability.

\section{Democratic Deficits}

The normal legislative process in liberal democracies is complex and archaic, ${ }^{18}$ often incomplete and inadequate. ${ }^{19}$ Nevertheless, a system based on representative democracy and a separation of powers is designed in such a way that the legislature, as an elected body, undertakes close scrutiny of government proposals in a climate of deliberation, seeking to identify and maximize a national consensus where feasible. The legislature puts a break on the unfettered adoption of laws, whilst at the same time giving voice to the constituents that are represented in the House.

There are a number of procedures and checks that help support this scrutiny. In the United Kingdom, these include various readings of a bill, parliamentary debate, the work of committees and a bicameral system, whereby a bill requires, for the most part, agreement in both Houses. In addition, whilst most bills are introduced directly into Parliament, a comparatively recent feature of the legislative process can involve the publication of a draft bill by the government and its scrutiny by a parliamentary committee, usually in the Parliamentary session preceding that in which a bill is formally introduced to Parliament. ${ }^{20}$ There is - as a rule - wide consultation on policies and proposals that may develop into legislation. A twostep procedure of white papers and green papers is used to discuss and consult government policy on a step by-step basis. Stakeholders and interest groups, as well as citizens, are invited to put forward their views throughout the process. ${ }^{21}$

Emergency legislation, by contrast, is frequently fast-tracked, meaning that a bill passes through all the normal stages of passage in each House, but on an expedited timetable. ${ }^{22}$ As has been previously stated,

17 Oren Gross (1998), 'Once More unto the Breach: The Systemic Failure of Applying the European Convention on Human Rights to Entrenched Emergencies', Yale Journal of International Law, 23(1).

18 See Mark Elliot \& Robert Thomas, Public Law (Oxford: Oxford University Press, 2017), at 220.

19 Sir Stephen Laws, 'What is the Parliamentary Scrutiny of Legislation for?', in Alexander Horne \& Andrew Le Sueur (Eds.) Parliament, Legislation and Accountability (Hart Publishing, 2016), at 15.

20 See Catherine Lynch \& Shane Martin (2019), 'Can Parliaments be Strengthened? A Case Study of Pre-Legislative Scrutiny', Irish Political Studies, 35(1).

21 Wim Voermans, Hans-Martien ten Napel \& Reijer Passchier (2015), 'Combining Efficiency and Transparency in Legislative Processes', The Theory and Practice of Legislation, 3(3), at 287.

22 See Richard Kelly, 'Fast-track Legislation', House of Commons Library, Briefing Paper Number 05256, 25 March 2020. 
[1]ike an express train, a bill on the 'fast-track' will pass through all its normal 'stops' (i.e. the various stages in each House), but the intervals between each stop will be shorter than on the 'slow line'. ${ }^{23}$

Normally, the legislative process can take several months. The Coronavirus Bill thus took approximately four days to become an Act of Parliament. As Wagner notes, a whale of a bill with its huge impact on personal freedoms, would ordinarily start as a white paper and a consultation lasting months, followed by months more of debate, amendments and committee stages. ${ }^{24}$ This example is not an isolated event, but rather a feature of emergency legislation adopted in response to COVID-19. In Scotland, for instance, the Coronavirus (Scotland) Bill passed through the full legislative process at Holyrood in a single day.

On one level, the expedited nature of the fast-track process is necessary to respond at speed to the emergency at hand. When more people, or groups of people, are involved in decision-making processes, these processes run the risk of slowing down and becoming less efficient. ${ }^{25}$ This, in turn, can impede the ability to address the situation and, in the case of COVID-19, could well have led to even greater numbers of people contracting the virus and dying.

And yet, there are obvious implications for democracy and accountability. Most obviously, fast-tracked procedures reduce the time available for elected representatives to deliberate on a bill and propose changes, thereby increasing the likelihood of legal errors or of the legislation having unintended consequences. Indeed, Liberty has argued that the need for proper parliamentary debate, and scrutiny is

an essential feature of the UK's constitutional structure ... when legislation is introduced into Parliament and passed within a few weeks or even days it is impossible for Parliament fully to analyse and debate the proposals put before it. $^{26}$

Although both Houses normally benefit from the reports of the expert Lords committees on the Constitution and on Delegated Powers and Regulatory Reform, and from the Joint Committee on Human Rights, with fast-tracked bills that is not practicable, although some members of those committees will no doubt take part in the debates, and Parliament will as ever be able to rely on the excellent briefings al Implications and Safeguards', HL 116-1 Session 2008-9, at Para. 12. Adam Wagner, 'Can We Make Good Laws During a Bad Pandemic?', Prospect Magazine (16 April 2020). Wim Voermans, Hans-Martien ten Napel \& Reijer Passchier (2015), 'Combining Efficiency and Transparency in Legislative Processes', The Theory and Practice of Legislation, 3(3), at 280.

26 Liberty, Memorandum by Liberty, at Para. 10; House of Lords, Constitution Committee: Fifteenth Report, 'Fast-Track Legislation: Constitutional Implications and Safeguards', HL 116-1 Session 2008-9. 
on different parts of the bill produced and published by the House of Commons Library. $^{27}$

In contrast to formal debate, little is often known about how fast-tracked legislation is agreed, under which conditions it occurs and what the political and democratic consequences are. ${ }^{28}$ Fast-track approaches remove the possibility of holding elected representatives accountable for their position on particular bills. ${ }^{29}$ Similarly, others such as Professor Brice Dickson, in submissions to The House of Lords Constitution Committee's report on fast-tracked legislation, referred to the 'important principle ... of participative democracy. ${ }^{30} \mathrm{He}$ assessed that 'the faster legislation is put through without prior notice, the more difficult it is for people outside Parliament, let alone parliamentarians, to express a view on the proposed legislation, and that is very regrettable. ${ }^{31}$

In addition, enabling legislation in the form of Acts of Parliament are given life through statutory instruments. For instance, curtailments on shops, places of entertainment, churches and citizen movements have been achieved for England by a relatively short statutory instrument, the Health Protection (Coronavirus, Restrictions) (England) Regulations 2020 (SI 350). These and other regulations were the subject of no debate at all. The lack of parliamentary scrutiny can be seen in the broad array of statutory instruments adopted to date, subject to the 'made negative' procedure - requiring no prior scrutiny at all, and, therefore, bypassing the authority of Parliament. ${ }^{32}$ As Wagner notes,

[t]his scrutiny vacuum will continue as long as the regulations stay in force. That is a huge amount of power for the executive which, as the emergency goes on for weeks, months, perhaps even years, becomes ever-less defensible. ${ }^{33}$

Thus, emergency legislation that is, in the first instance, fast-tracked often sidelines existing processes of debate and scrutiny in favour of an approach which has neither or limited incarnations of both. This undermines democratic deliberation and accountability. Moreover, once passed, enabling Acts such as the Coronavirus Act and the Public Health (Control of Disease) Act 1984 serve as the legal bases for statutory instruments, which are subject to no debate and passed at the discretion

27 David Natzler, 'Parliament and COVID-19: The Coronavirus Bill and Beyond', The Constitution Unit (23 March 2020). See also Joint Committee on Human Rights, Legislative Scrutiny Update (HC 1077 HL 157 2012-23), at Para. 25.

28 Christine Reh, Adrienne Héritier, Edoardo Bressanelli \& Christel Koop (2011), 'The Informal Politics of Legislation: Explaining Secluded Decision Making in the European Union', Comparative Political Studies, 46(9).

29 Sir Stephen Laws, 'What is the Parliamentary Scrutiny of Legislation for?', in Alexander Horne \& Andrew Le Sueur (Eds.) Parliament, Legislation and Accountability (Hart Publishing, 2016), at 29.

30 Bryce Dickson, Examination of Witnesses, Fast-track Legislation: Constitutional Implications and Safeguards - Constitution Committee, 18 March 2009 (Questions 226-239).

31 Ibid. Paul Daly, 'Some Notes on Emergency Legislation', Administrative Law Matters (15 March 2020).

32 Jake Hinks, 'The Coronavirus Act 2020: An Example of 'Excessive Executive Dominance', UK Constitutional Law Blog (9 June 2020).

33 Adam Wagner, 'Can We Make Good Laws During a Bad Pandemic?', Prospect Magazine (16 April 2020). 
of the Secretary of State. In both cases, transparency, accountability and democracy are undermined.

\section{Risk Abuse and Normalization of Emergency Powers}

The purpose of fast-tracked legislation is, in essence, the swift transfer of certain powers to the government so that they might respond in haste to the crisis at hand. Consider, for instance, the Coronavirus Act. ${ }^{34}$ Under the Act, various surveillance powers are widened in terms of authorizing authorities for the taking and retention of personal data. ${ }^{35}$ More direct intrusions into civil liberties include regulatory powers to direct the suspension of port operations, ${ }^{36}$ which are intended to ensure border monitoring when short-staffed but could also be applied internally (such as to marinas). Powers in the Coronavirus Act 2020 allow the police and immigration officials to take those they think are 'potentially infectious' with the coronavirus to a testing facility. ${ }^{37}$ Public health officers and other officials can enforce quarantining under Section 51. Section 52 allows for regulations to ban events, gatherings and the use of communal premises aimed at the apparently healthy general population. Under Schedule 21 of the Coronavirus Act, police, immigration officers and public health officers are permitted to detain anyone they have 'reasonable grounds' to suspect is 'potentially infectious' ${ }^{38}$ for up to 14 days. ${ }^{39}$

In light of the extent of these powers, there is, naturally, disagreement over the necessity of emergency measures and their relationship with human rights. Neve Gordon and Catherine Rottenberg hold that governments need the flexibility to address emerging threats and to exercise all power vested in the state to alleviate the situation. ${ }^{40}$ Similarly, David Isaac assesses that the restrictions being extended by emergency coronavirus legislation are designed to protect those in vulnerable situations and safeguard our future. ${ }^{41}$ Exception requires concrete decisions that are not, and cannot be, constrained or guided by any sort of a priori rules. ${ }^{42}$ For Davidson, the starting point of any analysis of emergency measures should be the impact of the pandemic itself, to which these powers are a response. In particular, it should be recognized that the pandemic engages the most fundamental right

34 See for an overview of the Coronavirus Act, from which the above discussion is drawn: Clive Walker \& Andrew Blick, 'Coronavirus Legislative Responses in the UK: Regression to Panic and Disdain of Constitutionalism', Just Security (12 May 2020). See also Liberty's Briefing on the Coronavirus Bill March 2020.

35 Sections 22-24.

36 Section 50.

37 Jennifer Brown, 'Coronavirus: The Lockdown Laws', House of Commons Library (6 August 2020).

38 Para. 7(1).

39 Para. 15(1).

40 Neve Gordon \& Catherine Rottenberg, 'The Coronavirus Conundrum and Human Rights', Counterpunch (24 March 2020).

41 David Isaac, 'Human Rights and Equality Considerations in Responding to the Coronavirus Pandemic', Equality and Human Rights Commission (19 March 2020).

42 Oren Gross (2000), 'The Normless and Exceptionless Exception: Carl Schmitt's Theory of Emergency Powers and the Norm-exception Dichotomy', Cardozo Law Review, 21(5-6), at 1827. 
afforded by the European Court of Human Rights (ECHR): "the right to life." 43 By contrast, others lament that in the United Kingdom, as with elsewhere, emergency measures adopted in response to the pandemic have significantly and, in the view of some, disproportionately impacted on rights. Lord Sumption, a consistent opponent of lockdown measures, has noted that '[w]e have subjected most of the population, young or old, vulnerable or fit, to house imprisonment for an indefinite period.' 44 The potential for excessive use of power under periods of emergency is highlighted as particularly detrimental to human rights. Difficulties have centred around the extent of powers afforded to the police, uncertainties surrounding law and guidelines, ${ }^{45}$ and the misapplication of these powers. ${ }^{46}$

Yet, limitations on liberty are often accepted as justified in the name of dealing with emergencies, as are enhanced authorities, expanded functions, and greater discretionary powers. One of the major difficulties associated with emergency powers, whether under a state of emergency or otherwise, is determining when the competencies afforded to the executive and arms of the state ought to cease. There are very real concerns that emergency measures, adopted to deal with extraordinary times, become the new norm. ${ }^{47}$ For Elliot Bulmer:

$[\mathrm{M}]$ any governments have used emergency powers inappropriately - needlessly prolonging or renewing states of emergency, and using emergency powers not to restore democratic normality but to bypass normal channels of democratic accountability, harass dissidents, rig elections, restrict the press, and ultimately to set aside a nominally democratic constitution and impose a dictatorial regime. ${ }^{48}$

43 Leo Davidson, 'The Coronavirus Lockdown Does Not Breach Human Rights (Part One)', UK Human Rights Law Blog (30 April 2020). See also Elizabeth Stubbins Bates, 'Article 2 ECHR's Positive Obligations - How Can Human Rights Law Inform the Protection of Health Care Personnel and Vulnerable Patients in the COVID-19 Pandemic?', Opinio Juris (1 April 2020); Elizabeth Stubbins Bates \& C. Mallory, 'The Importance of Human Rights Law in the Covid-19 Pandemic' (manuscript under review, April 2020); Conall Mallory, 'The Right to Life and Personal Protective Equipment', UK Constitutional Law Blog (21 April 2020); Paul Bowen, 'Learning Lessons the Hard Way - Article 2 Duties to Investigate the Government's Response to the Covid-19 Pandemic', UK Constitutional Law Blog (29 April 2020); Garden Court Chambers, 'Legal Challenge Against UK Government's Guidance about Personal Protective Equipment in Hospitals' (23 April 2020).

44 Jonathan Sumption, 'The Only Coherent Position is Locking Down Without Limit - Or Not Locking Down At All', Prospect Magazine (26 May 2020).

45 See, e.g. Raphael Hogarth, 'The Government Must Draw a Clear Line Between Law and Guidance During the Coronavirus Crisis', Institute for Government (1 April 2020); Raphael Hogarth, 'The Government Needs to Tell Parliament How It Will Address Problems with the Lockdown Laws', Institute for Government (4 May 2020).

46 Owen Bowcott, 'Man Wrongly Convicted Under Coronavirus Law, Met Police Admit', The Guardian (14 April 2020).

47 Marc de Wilde (2015), 'Just Trust Us: A Short History of Emergency Powers and Constitutional Change', Comparative Legal History, 23(1); Sascha Mueller (2016), 'Turning Emergency Powers Inside Out: Are Extraordinary Powers Creeping Into Ordinary Legislation?', Flinders Law Journal, 18(1).

48 Elliot Bulmer (2016), Emergency Powers, International IDEA Constitution-Building Primer, at 7. 
Concerns surrounding the extent of powers afforded under emergency legislation are thus compounded by temporal uncertainties. In short then, whilst many (although certainly not all) accept that some deviation from normal human rights protections are part and parcel of how a particular country attempts to respond to emergencies, there are nevertheless significant risks that these powers will be abused in ways that are disproportionate and that emergency powers will become the norm.

\section{Accountability Deficits}

The final issue discussed relates to accountability, and is one that flows directly from the extent of powers that are transferred through emergency legislation and the uncertainty regarding their duration. ${ }^{49}$ In those contexts where autocratic-leaning leaders are exploiting COVID-19 to cement their grip on power, emergency legislation has only sought to further erode existing checks and balances. ${ }^{50}$ Even in more liberally minded states, however, there is often little in the way of oversight. In the United Kingdom, for instance, scholars such as Walker and Blick identify that existing legislation in the way of the Civil Contingencies Act 2004 provided significantly stronger checks on government power during emergencies. Under this Act, a senior Minister of the Crown is empowered in certain circumstances - which are likely to be deemed met at present - to make very broad-ranging emergency regulations. However, regulations under the 2004 Act must be ratified by Parliament within 7 days of being made. Furthermore, such regulations expire after 30 days. Thereafter they must then be renewed and re-ratified. This means that for any power granted under the Civil Contingencies Act 2004 to remain in force for the duration of the crisis, Parliament would have to meet at least every 30 days.

By contrast, scanty oversight mechanisms are applied to the Coronavirus Act. ${ }^{51}$ First, by Section 97, the Secretary of State must publish every two months a report on the status of the provisions, including a statement of satisfaction that the live status of those provisions is 'appropriate,' though according to unstated criteria.

49 While beyond the confines of this paper, there is a lively debate surrounding the vires of regulations passed under the Public Health (Control of Disease) Act 1984. Jeff King, 'The Lockdown is Lawful', UK Constitutional Law Blog (1 April 2020); Jeff King, 'The Lockdown is Lawful: Part II', UK Constitutional Law Blog (2 April 2020); Tom Hickman, 'Coronavirus and Civil Liberties in the UK', Blackstone Chambers (6 April 2020); Robert Craig, 'Lockdown: A Response to Professor King', UK Human Rights Law Blog (6 April 2020); Francis Hoar, 'A Disproportionate Interference: The Coronavirus Regulations and the ECHR', UK Human Rights Blog (21 April 2020); Lord Sandhurst QC \& Anthony Speaight QC, 'Pardonable in the Heat of Crisis - But We Must Urgently Return to the Rule of Law', UK Human Rights Blog (9 April 2020); Leo Davidson, 'The Coronavirus Lockdown Does Not Breach Human Rights (Part One)', UK Human Rights Law Blog (30 April 2020); Dominic Ruck Keene \& Henry Tufnell, 'Leviathan Challenged - The Lockdown is Compliant with Human Rights Law (Part Two)', UK Human Rights Blog (11 May 2020).

50 Anne Applebaum, 'Creeping Authoritarianism Has Finally Prevailed: In Hungary, the Pandemic was Just an Excuse', The Atlantic (3 April 2020); Laura Livingston, 'Understanding Hungary's Authoritarian Response to the Pandemic', Lawfare (14 April 2020); Selen Eşençay, 'When COVID-19 Becomes a Political Ally: Poland's Law on Abortion', LSE Engenderings.

51 See Clive Walker \& Andrew Blick, 'Coronavirus Legislative Responses in the UK: Regression to Panic and Disdain of Constitutionalism', Just Security (12 May 2020); Andrew Blick \& Clive Walker, 'Why Did Government Not Use the Civil Contingencies Act?', The Law Society Gazette (2 April 2020). 
Second, by Section 98, the House of Commons can debate and vote on the continuation of the Coronavirus Act 2020 every six months based on a motion 'That the temporary provisions of the Coronavirus Act 2020 should not yet expire.' This review power, according to Walker, is extraordinarily limited. The wording stacks the odds in favour of renewal and banishes the House of Lords from any formal role. The third precaution is that, by Section 89, the Act is to expire after two years (and measures can be suspended or revived within that time: Section 88). Even so, a 'relevant national authority' under Section 90 (a Minister of the Crown) can extend the life by regulation for six months at a stretch. ${ }^{52}$

It is debateable as to whether the Civil Contingencies Act would, in fact, have been preferable. Nevertheless, one of the outstanding questions is why, given the extensive powers already established under existing legislation, stand-alone legislation of a duration of potentially more than two years is strictly necessary in response to this public health emergency. The implications are that the levels of oversight and accountability have not widened in line with the broadening of powers afforded to the government. ${ }^{53}$ On the contrary, in overlooking the existing Civil Contingencies Act, the government's approach requires considerably less accountability and review than would have been required under that legislative scheme. Moreover, the role of parliament in scrutinizing the government has also been hampered as a result of social distancing. ${ }^{54}$ Thus, emergency legislation, despite giving significant power to the government, is not accompanied by adequate levels of accountability that we might expect.

\section{A Necessary Interlude}

Thus, emergency legislation that is fast-tracked omits the necessary scrutiny that attaches to normal parliamentary processes. This, in turn, can have adverse implications on democracy, particularly when elected leaders are denied the opportunity to adequately debate the Bill in question. The powers afforded to government are significant, impacting adversely on the enjoyment of human rights. Whilst perhaps necessary in immediate responses to an emergency, there are risks that these powers become the norm. Moreover, the expanded nature of discretion and powers is often not accompanied by increased levels of oversight and accountability. It is against this backdrop that sunset clauses might be of use.

Prior to proceeding, however, it is necessary to pause and identify another oddity associated with the UK approach. Despite passing the Coronavirus Act in March 2020 and as already alluded to, the most draconian restrictions on civil liberties have come in the way of delegated legislation under the Public Health Act 1984. The former includes a sunset clause, whereas the latter does not. Thus, one could be forgiven for questioning the real relevance of an article on sunset clauses.

52 See for further discussion, Section $C$ of this article.

53 For some, existing accountability mechanisms are already far from satisfactory. See Benoit Guerin, Julian McCrae \& Marcus Shepheard, 'Accountability in Modern Government: Recommendations for Change', Institute for Government.

54 Alice Lilly \& Hannah White, 'Parliament's Role in the Coronavirus Crisis: Holding the Government to Account', Institute for Government. Although as noted in this report, in some cases, such as with select committees, working remotely has improved accountability. 
Nevertheless, the discussion is relevant for a number of reasons. Firstly, beyond the United Kingdom, sunset clauses have featured in other pieces of emergency legislation. In Ireland, the powers under The Health (Preservation and Protection and other Emergency Measures in the Public Interest) Act 2020 will cease to have effect after 9 November 2020, unless a resolution is passed by both houses of the Oireachtas (parliament) to approve the continuation of the measures. In Scotland, the Coronavirus (Scotland) Act includes a 'sunset clause', according to which most of it will automatically expire six months after it comes into force. Members of the Scottish Parliament will be able to vote to extend this for another six months if necessary, and then for another six months after that, but this is the absolute limit - so the measures in the bill have a maximum duration of 18 months. ${ }^{55}$ In Germany, sunset clauses are provided for measures under the federal Infectious Disease Prevention Act (IDPA), and the corresponding powers of the federal government are available only if a 'pandemic state of emergency' has been proclaimed by the Bundestag (Federal Parliament). ${ }^{56}$ Similarly, in Singapore, sunset clauses within executive regulations, promulgation and re-promulgation review are subject to Parliamentary scrutiny upon expiry. ${ }^{57}$ Sunset clauses, therefore, are a feature of the wider pandemic legislative context and relevant beyond the UK context.

Secondly, particularly when considering the positive aspects or potential of sunset clauses, the discussion adds to the debate on whether the Coronavirus Act rather than the Public Health Act ought to have been used when passing statutory instruments. For instance, in considering the discussion surrounding the legality of regulations enacted under the Public Health Act, Grogan notes that:

An answer [to the debate on whether regulations are ultra vires], and preferred in my opinion, would have been for the lockdown to have been based on an Act of Parliament with such legislative scrutiny and appropriate democratic, rights and rule of law safeguards as this would provide. This could even have been within the Coronavirus Act 2020, which would then supersede and replace the Regulations which are secondary legislation made by government ministers. ${ }^{58}$

If, then, sunset clauses have the potential to reinject scrutiny and review processes where Health Regulations have been lacking, their potential takes on a normative bent in the context of these wider debates. Thirdly, and as developed below, sunset clauses rarely provide for a definitive termination on a prescribed date. Rather, they more often than not require a review of existing legislation. This review-relat-

55 See Scottish Government, Coronavirus (Scotland) Act 2020 and the Coronavirus (Scotland) (No. 2) Act 2020 - proposed extension: statement of reasons (28 August 2020).

56 Liora Lazarus, 'Introduction', in Bonavero Institute of Human Rights, A Preliminary Human Rights Assessment of Legislative and Regulatory Responses to the COVID-19 Pandemic across 11 Jurisdictions Bonavero Report No. 3/2020 6 May 2020, at 14.

57 Sanya Samtani, 'Singapore', in Bonavero Institute of Human Rights, A Preliminary Human Rights Assessment of Legislative and Regulatory Responses to the COVID-19 Pandemic across 11 Jurisdictions Bonavero Report No. 3/2020 6 May 2020, at 89.

58 Joelle Grogan, 'Right Restriction or Restricting Rights? The UK Acts to Address COVID-19', Verfassungsblog (17 April 2020). 
ed element makes the discussion on sunset clauses applicable to most legislative responses to the pandemic. For, as developed in Section D, in order to be effective, the utility of sunset clauses is wholly dependent on the degree to which the legislation they attach to is properly debated and reviewed. With these ideas in mind, the discussion below now considers how, in theory, sunset clauses might help address the concern highlighted above in relation to emergency legislation.

\section{The Theory of Sunset Clauses}

The precise origins of sunset clauses are contested. Some locate their roots in Roman law, but the first philosophical reference is in the laws of Plato. At the time of the Roman Republic, the empowerment of the Roman Senate to collect special taxes and to activate troops was limited in time and extent. Those empowerments ended before the expiration of an electoral office, such as the Proconsul. ${ }^{59}$ In the United Kingdom, sunset clauses were employed by parliaments by at least the time of the reign of Henry VII and appeared in statutes by 1500. The series of Habeas Corpus Suspension Acts enacted from 1689 all had specified expiry dates; up until 1777, these acts lasted on average for five months. In the United States, Chris Mooney traces the history of sunsetting back to the writings of Thomas Jefferson. ${ }^{60}$

In modern times, alongside their usage in the context of taxation and tax law, ${ }^{61}$ sunset clauses have mostly been associated with emergency legislation introduced in the wake of the terrorist attack of September $11 .{ }^{62}$ In the United States, for instance, the Patriot Act was enacted in late October 2001, and made sweeping changes to many laws pertaining to counterterrorism. It included a sunset clause to trigger at the end of 2005. In the United Kingdom, The Anti-terrorism, Crime and Security Act 2001 (ATCSA) provided for further terrorist offences and counterterrorism powers not covered under the existing Terrorism Act 2000. The operative sections were set to expire in 15 months, but the secretary of state could extend the expiry date for 12-month periods. The Terrorism Act 2006, enacted after the London bombings of July 2005, was subject to a 12-month sunset clause, but the expiry date was again extendable by parliament.

59 See, for an excellent discussion of the origins of sunset clauses, Antonios E. Kouroutakis, The Constitutional Value of Sunset Clauses: An Historical and Normative Analysis (Routledge, 2017). See also Sean Molloy, 'Coronavirus and parliament: A Brief History of Sunset Clauses', Prospect Magazine (28 April 2020); Sean Molloy, 'Covid-19, Emergency Legislation and Sunset Clauses', UK Constitutional Law Blog (8 April 2020).

60 Chris Mooney, 'A Short History of Sunsets' (January-February 2004), Legal Affairs.

61 See, e.g. Rebecca M. Kysar (2011), 'Lasting Legislation', University of Pennsylvania Law Review, 159(4); Rebecca M. Kysar (2006), 'The Sun Also Rises: The Political Economy of Sunset Provisions in the Tax Code', Georgia Law Review, 40(2).

62 See John Ip (2013), 'Sunset Clauses and Counterterrorism Legislation', Public Law, 74(1); Emily Berman (2013), 'The Paradox of Counterterrorism Sunset Provisions', Fordham Law Review, 81(1). 
In theory, sunset clauses provide a partial response to the difficulties posed by emergency legislation outlined above. ${ }^{63}$ For one, sunset clauses allow for the termination of emergency powers transferred under legislation. Such a device thus makes the law to which it applies temporary, whereas legislation is ordinarily permanent in that it persists unless and until repealed by subsequent legislation. ${ }^{64}$ In the United Kingdom and as previously outlined, the sunset date of the Coronavirus Act is set out in Section 89 of the Act. The Act expires at the end of the period of two years beginning with the day on which it is passed, subject to Subsection (2) and Section 90. As the date it was passed is set out in the Act (25 March 2020), we know the Act will expire on 25 March 2022.

Thus, sunsetting emergency legislation is a way of attempting to ensure that these measures are temporary by stipulating when emergency legislation ceases to have effect. A useful example in this regard comes from Canada and the Canadian Anti-Terrorism Act. ${ }^{65}$ The most controversial provisions - 'those concerning the power to compel reluctant witnesses to reveal information relevant to terrorism investigations in investigative hearings and the power to make preventive arrests in terrorism cases' - were made subject to a five-year sunset clause, which were allowed to expire in March 2007. ${ }^{66}$ It follows that whilst emergency legislation encroaches on individual rights and expands the power of the state, sunset clauses can serve to stave off the risks associated with the potential permanence of these measures or the accountability deficits that arise with them.

Of course, it is also the case that emergency laws may well persist longer than the stipulated sunsetting period. Indeed, McGarrity et al. note that it is unrealistic to expect that sunset clauses will always result in the expiry of legislation and, indeed, in some cases, the most appropriate decision will be to renew the legislation. ${ }^{67}$ The current pandemic is as unpredictable as it is deadly. It is wholly possible that if and when further outbreaks occur, governments must be responsive to these changes. This is where the review aspect of sunset clauses becomes so important, in particular its ability to reinject parliamentary oversight and democracy. ${ }^{68}$ For instance, Section 90 of the Coronavirus Act grants the power to (with the agreement of Parliament) alter the expiry date. It can be extended for up to six months, and this power can be exercised repeatedly. In addition, Section 98 of the Coronavirus Act 2020 sets out a procedure for a six-month parliamentary review. If Parliament rejects a motion 'that the temporary provisions of the Coronavirus Act 2020 should not yet expire', then there is a procedure to be followed to terminate the Act. This renewal 'trigger' automatically comes up every six months,

63 Although in the particular context of the United Kingdom, the limitations should also be noted. Some of the most severe restrictions on individual liberties have come not from the Coronavirus Act but rather regulations under the Public Health (Control of Disease) Act 1984. There are also different pieces of legislation.

64 Jacob E. Gersen (2007), 'Temporary Legislation', University of Chicago Law Review, 74(1), at 261.

65 SC 2001, c 41.

66 Nicola McGarrity, Rishi Gulati \& George Williams (2012), 'Sunset Clauses in Australian Anti-Terror Laws', Adelaide Law Review, 33(2), at 321.

67 Ibid., at 322.

68 Franklin De Vrieze, 'Preparing the Roll-Back of COVID-19 Emergency Legislation', Institute of Advanced Legal Studies (27 April 2020). 
meaning that every six months, Parliament has a guaranteed opportunity to be able to terminate the Act. A renewal trigger is one of the checks and balances that Ackerman envisaged when he said that 'the need for repeated renewal at short intervals serves as a first line of defence against a dangerous normalization of the state of emergency'. ${ }^{6}$

In response to uncertainties surrounding the undemocratic nature of emergency legislation and scant oversight of emergency powers, review processes thus reinject the necessary parliamentary oversight that is often lacking when laws are passed in haste. ${ }^{70}$ These provisions necessarily invite post-legislative scrutiny of the legislation in question looking at the impact of legislation; whether the intended policy objectives of the law have been met and how effectively. ${ }^{71}$ It can also examine whether limitations on rights are reasonably justifiable in the circumstances and are for the purpose of dealing with the coronavirus. For Kouroutakis then,

sunset clauses are an appropriate mechanism to allow wide delegated powers and simultaneously enhance parliamentary oversight during the whole process. Unless re-authorized by the legislature, a sunset clause brings about the expiration of the delegated power on a prescribed date. ${ }^{72}$

Moreover, even where the sunset is extended, review processes can nevertheless be important both in terms of inviting wider consultation and participation that push through amendments to the legislation in question. A useful example is offered by McGarrity et al. in the form of the post-enactment review of the Special Powers Regime in Australia. ${ }^{73}$ The sunset clause in the Australian Security Intelligence Organisation Act 1979, Legislation Amendment Act 2003, provided that the Special Powers Regime would expire on 23 July 2006 and charged a Joint Committee with the task of reviewing the legislation prior to its expiry. The Joint Committee comprised members of the Coalition Government of the time and the Opposition. Amongst other things, the Joint Committee published information about the review, and a public call for submissions were advertised in a national Australian newspaper. It also prepared a background paper detailing some of the issues for consideration, ${ }^{74}$ and held various hearings and invited key witnesses from academia, government, independent agencies, community organizations and the legal profession to provide evidence in relation to the terms and operation of the legislation. ${ }^{75}$ Although the Joint Committee concluded that the Special Powers Regime should remain in force, it made 19 recommendations for amendments to the legis-

69 See Bruce Ackerman (2004), 'The Emergency Constitution', Yale Law Journal, 113(5).

70 Sofia Ranchordas, Constitutional Sunsets and Experimental Legislation: A Comparative Perspective (Edward Elgar Publishing, 2015).

71 See Philip Norton (2019), 'Post-legislative Scrutiny in the UK Parliament: Adding Value', The Journal of Legislative Studies, 25(3).

72 Antonios Kouroutakis (2020), 'The Virtues of Sunset Clauses in Relation to Constitutional Authority', Statute Law Review, 41(1), at 20.

73 Nicola McGarrity, Rishi Gulati \& George Williams (2012), 'Sunset Clauses in Australian Anti-Terror Laws', Adelaide Law Review, 33(2), at 320.

74 Ibid.

75 Ibid., at 322. 
lation. Some of these recommendations addressed the overreach and substantial human rights failings of the legislation. These recommendations included (a) the issuing authority be satisfied that other methods of intelligence gathering would not be effective (Recommendation 1); (b) greater access by persons subject to a warrant to effective legal representation (Recommendations 4, 5, 7 and 9); and (c) increasing the transparency surrounding the Special Powers Regime, such as by narrowing the definition of 'operational information' and repealing the offence of disclosing the existence of a warrant (Recommendations 16 and 17). ${ }^{76}$ McGarrity et al. identify that the Coalition responded positively to the Joint Committee's report agreeing with six recommendations and in part with a further six. ${ }^{77}$

It is for these reasons and others that sunset clauses with review procedures are frequently promoted. The House of Lords Select Committee on the Constitution has previously stipulated that:

Where fast-tracked bills are used, there needs to be an additional safeguard. We therefore recommend that, in such cases, there should instead be a presumption in favour of the use of a sunset clause. By this process, a piece of legislation would expire after a certain date, unless Parliament chooses either to renew it or to replace it with a further piece of legislation subject to the normal legislative process. ${ }^{78}$

In addition, with the prospect of emergency measures sunsetting and review processes to determine the continuation or cessation of emergency powers, sunset clauses can enable expeditious responses. For Underhill et al., the principal virtue of sunset clauses is that they are a recognizable means of securing passage of legislation with strong opponents, ${ }^{79}$ making initial agreement more tractable. ${ }^{80}$

Read together, sunset clauses and review processes attached to them 'limit the duration of extraordinary powers and guarantee a more frequent dialogue between the executive and parliament'. ${ }^{81}$ They also 'promote democratic oversight and accountability by providing the legislature with periodic opportunities to revisit questions with the additional information or experience necessary to adjust or to recalibrate public policy.' ${ }^{82}$ When included in emergency legislation, sunset provisions can be a mechanism by which democracies devise ways to accommodate governmental powers within a pre-established legal framework, rather than leave it to

81 Antonios Kouroutakis \& Sofia Ranchordas (2016), 'Snoozing Democracy: Sunset Clauses, De-Juridification, and Emergencies', Minnesota Journal of International Law, 25(1), at 34.

82 John E. Finn (2010), 'Sunset Clauses and Democratic Deliberation: Assessing the Significance of Sunset Provisions in Antiterrorism Legislation,' Columbia Journal of Transnational Law, 48(3), at 447. 
governments to use raw power and untrammelled discretion to deal with emergencies in an unregulated way. They are also crucial in helping to bridge political stalemates, allowing necessary transfers of power to occur with the security of subsequent cessation or deliberation.

\section{Sunset Clauses: Approach with Caution}

Nevertheless, despite the potential for sunset clauses to perform these various roles, there are reasons to be sceptical. Firstly, whilst sunset clauses can facilitate compromise, their inclusion can be used to garner cross-party approval to push through contentious pieces of legislation only for them to be later removed. By including sunset clauses, opponents of particular bills (largely because of the wide powers that are afforded under them) are reassured that any measures are timebound. But this does not necessarily safeguard sunset clauses from political lobbying and subsequent amendments post adoption. A frequent criticism of sunset clauses is that they provide a convenient political excuse for shortcutting initial parliamentary debate about controversial legislation, thereby postponing the substantive debate until the legislation comes up for expiry or renewal. Of even greater concern is the suggestion that a sunset clause operates as the 'spoonful of sugar that helps controversial legislation go down. ${ }^{83}$ For instance, the first Bush tax cut was passed in 2001 to terminate at the close of 2010. No sooner had the laws been passed than their Republican backers launched a pre-emptive strike, criticizing the sunsets and attempting to undo them. The Republican-led House of Representatives subsequently voted to make permanent the repeal of the estate tax contained in Bush's first tax cut. ${ }^{84}$ Thus, in the context of taxation, Manoj Viswanathan assesses that

sunset provisions ... are the product of political manoeuvring designed to bypass budgetary constraints and are exploited as a means of enacting permanent legislation under the guise of an ostensible expiration date. ${ }^{85}$

In short, the use of sunset clauses, whilst facilitating compromise, can be used as a political tool through which to achieve legislative goals with no real intention of honouring the proposed end date.

Secondly, and building directly on, the addition of sunset clauses notwithstanding, pieces of emergency legislation can remain in force long after the proposed sunset. It will be remembered that part of the logic of sunsetting legislation is to ensure that emergency powers do not normalize. But because most sunset clauses allow subsequent extensions, there are no guarantees that the legislation in question will cease to have effect. This is more likely when, with terrorism as with

83 Chris Mooney, 'A Short History of Sunsets' (January-February 2004), Legal Affairs.

84 Sean Molloy, 'Coronavirus and Parliament: A Brief History of Sunset Clauses', Prospect Magazine (28 April 2020).

85 Manoj Viswanathan (2007), 'Sunset Provisions in the Tax Code: A Critical Evaluation and Prescriptions for the Future', New York University Law Review, 82(1). 
COVID-19, the enemy is invisible and thus unknown. In the United States, for instance, the 2001 Patriot Act adopted in the aftermath of the September 11 attacks included 16 sections originally meant to sunset on 31 December 2005. The Act was re-authorized several times in the following years following very limited evaluation. Similarly, in the United Kingdom, the Prevention of Terrorism Act 2005 (PTA) was renewed annually from 2005 until its repeal in December 2011 by the Terrorism Prevention and Investigation Measures Act 2011. Finn, in his international study, thus concluded that the expiry of anti-terrorism legislation is extremely rare. ${ }^{86}$ More often than not, legislation has been renewed for a longer period of time than the original sunset clause or even made permanent. The reality of sunset clauses, therefore, is that their promise of curtailing emergency powers to prevent normalization is often unfulfilled. For some, they are simply ineffective. ${ }^{87}$

Thirdly, when sunset clauses provide for further debate and scrutiny, the efficacy of the review process is of central importance. This is a central component when attempting to argue that sunset clauses are a way of reinjecting democratic participation and scrutiny deprived under fast-tracked processes. Yet, the mere provision of future scrutiny is no guarantee for the effectiveness of that process. As De Vrieze has noted: "Not all scrutiny is equal ... parliaments vary in scrutinising the implementation of legislation." ${ }^{88}$ But they also vary in how they scrutinize the necessity and proportionality of emergency legislation. The civil society group JUSTICE, for instance, has in the past voiced its scepticism about the quality of debate triggered by the sunset clauses in the Anti-Terrorism Crime and Security Act 2001 and the Prevention of Terrorism Act 2005, noting that:

the annual debates triggered by these measures have typically been rushed affairs and seem to us to offer little of the substantive scrutiny that is required in respect of such sweeping measures (indefinite detention of foreign nationals and control orders respectively. ${ }^{89}$

Similarly, the Counter-Terrorism Review Project highlights that in the 2003 debate in the House of Lords on whether to renew the Part 4 powers of the Anti-Terrorism, Crime and Security Act 2001, just four Lords spoke. ${ }^{90}$ This included the minister who had introduced the renewal order. Only $13 \mathrm{MPs}$ attended the first debate in 2006 on whether to renew the Prevention of Terrorism Act 2005 - the legislation which established the control order regime. There might also be financial or political reasons that deter effective reviews. Kearney has reported a survey of states with sunset legislation providing for agency review and discontinuation of governmental entities over time, and found that 12 states discontinued legislative

John E. Finn (2010), 'Sunset Clauses and Democratic Deliberation: Assessing the Significance of Sunset Provisions in Antiterrorism Legislation,' Columbia Journal of Transnational Law, 48(3).

87 Oren Gross (2003), 'Chaos and Rules: Should Responses to Violent Crises Always Be Constitutional?', The Yale Law Journal, 112(5).

88 Franklin De Vrieze, 'Not All Scrutiny is Equal: How Parliaments Vary in Scrutinising the Implementation of Legislation', Democratic Audit (25 March 2020).

89 The Law Commission, Post-Legislative Scrutiny, (Law Com No 302), at Para. 3.56.

90 See Counter-Terrorism Review Project, 'Sunset Clauses' (12 April 2018). 
sunset reviews 'because of high monetary and temporal costs of sunset review, intensive lobbying by vested interests, unfulfilled expectations of agency termination, low levels of citizen participation, and other perceived problems. ${ }^{91}$

Fourthly, the necessary period of time between adoption and review and between different review processes raises additional issues. Although the UK's Coronavirus Act allows for review after a period of six months, this may still be too infrequent. During the House of Lords review of Fast Track Legislation in 2009, for instance, The Better Government Initiative argued that 'post-legislative scrutiny is all the more necessary' in cases of fast-track legislation, and that 'it should perhaps be more frequent. ${ }^{92}$ Such is the nature of the pandemic and such is the extent and wide-ranging nature of powers afforded under the Coronavirus Act (and similar pieces of legislation adopted globally), that more review processes might be required. But how might this be achieved in light of social distancing? In addition, the time allotted for debates on sunset clauses is also very short, often limited by parliamentary procedure to only an hour and a half. ${ }^{93}$ In addition, there are questions regarding the most effective form of review. If parliamentary post-legislative review is the chosen approach, there may be problems associated with politicization of the legislation in question. Should, then, the review be undertaken by an independent expert, committees of the House of Commons or Lords, or an independent group? If so, how democratic would the process be? Of course, many of these are issues that arise in the context of any review process, but they nevertheless demonstrate that there is a range of considerations that flow from sunset clauses, which require ongoing scrutiny themselves.

\section{E Conclusion and the Need for a Cautious Approach to Review Processes}

Sunset clauses are and will continue to be included in emergency legislation adopted in response to the COVID-19 pandemic. They are unquestionably a useful mechanism by which to ensure that emergency provisions do not normalize, thereby entrenching powers that can adversely affect the enjoyment of individual rights and freedoms. At times, they merge with post-legislative scrutiny, conditioning the continuation of legislation on the basis of ongoing and periodic review processes. In doing so, they can ease what Gross termed the tension of 'tragic dimensions' between democratic values and responses to emergencies by reinjecting democratic oversight and accountability where previously lacking under fast-tracked approaches. ${ }^{94}$ However, there are limitations associated with sunset clauses. They can exist on paper, but have little impact in practice. They can be renewed on an ongoing basis, often with little or insufficient scrutiny. They can be utilized for political manoeuvring absent sincere intentions to honour the proposed sunset date.

91 Richard C. Kearney (1990), 'Sunset: A Survey and Analysis of the State Experience', Public Administration Review, 50(1), at 49.

92 House of Lords, Constitution Committee: Fifteenth Report, 'Fast-Track Legislation: Constitutional Implications and Safeguards', HL 116-1 Session 2008-9, at Para. 174.

93 See Counter-Terrorism Review Project, 'Sunset Clauses' (12 April 2018).

94 Oren Gross (2003), 'Chaos and Rules: Should Responses to Violent Crises Always Be Constitutional?', The Yale Law Journal, 112(5). 
Thus, adherence to sunset clauses must itself be scrutinized and approached with caution. When it comes to reviewing sunset clauses and emergency legislation, therefore, it will be important to consider the following questions. Who is reviewing the legislation? Is it Parliament, government, government departments? Who is being invited to participate? For instance, are human rights groups, civil society more generally and academics permitted to contribute? What is being examined? Is it, e.g. technical aspects, the relationship between the legislation and intended policy outcomes or the impact of emergency measures? If the latter, the impact on whom? What role does, for instance, age, class and gender play in the analysis? Is it merely primary legislation or also secondary legislation adopted under, for instance, the Coronavirus Act? To what extent are lessons from other contexts part of this analysis? How will the findings from the approximately 27 other established committees on COVID-19 feature in the review? Will there be a gender-sensitive approach to scrutiny? These are just a few of a range of potential questions that could be and ought to be asked.

The point is that when we are cautious about the use of sunset clauses, we can begin the conversation regarding the review processes that determine whether they will ultimately serve as safeguards of democracy or merely exist as legal tools utilized to achieve political outcomes, with little or no effect in practice. 